\title{
クメール寺院の石造壁と木造架構の接続技法
}

\section{ON THE TECHNIQUES OF THE WOOD FRAMES ON THE STONEWALLS IN KHMER ARCHITECTURE}

\author{
溝口明則*，中川＼cjkstart武**，小岩正樹***，石塚充雅****，黒岩千尋***** \\ Akinori MIZOGUCHI, Takeshi NAKAGAWA, Masaki KOIWA, \\ Mitsumasa ISHIZUKA and Chihiro KUROIWA
}

\begin{abstract}
In the monuments of Preah Vihear, there are many wooden roof traces that are part of the character of Preah Vihear. Although there are preceding studies of the wooden roof structure, there is many questions unanswered.In this paper, we studied the transition and technique of wooden roof structure from K oh K er to Preah Vihear by checking the methods of installation of the pole plate and beam at the upper part of the stone wall.

The methods employed devices that appeared and were updated over approximately 150 years. As the result of study, the process of transition takes from first half of the 10th century to around end of the 11th century and could be separated in 6 phases. The process of transition possibly provides a clue to understanding the age of building.
\end{abstract}

\footnotetext{
Keywords: Cambodia, Khmer Architecture, Preah Vihear, Wooden Structure, Eave Girder and Tie Beam, Joint Trace, カンボジア，クメール建築，プレア・ヴィヘア，木造架構，軒桁と梁，仕口痕跡，
}

\section{1. はじめに}

およそ 9 世紀から 13 世紀にかけて，東南アジア大陸部に広大な国 土を維持経営したクメール王朝は，王国各地に有力な地方拠点を設 置した。これらは大規模な石造寺院遺跡として各地に残っている。 なかでも特別な遺跡として知られるプレア・ヴイヘア寺院は，9世 紀末頃から聖地として王国の重要地方拠点であり続けた遺跡である。

クメールの寺院は, 早くからレンガ造であった中央祠堂を除き, 伽藍内の多くの施設が木造であったこと，およびこれらの施設が次 第に石造に置き換わっていったことは周知の事実である。その途上 で，石造の壁体とペディメントを設け，木造の小屋組と瓦莫屋根を 載せた木造と石造の混構造の時代が存在したこともよく知られてい る。プレア・ヴィヘア寺院は, クメール建築が全面的な石造化一至 る過渡期の時代に現れた木造の屋根と木造小屋組の痕跡を残寸石造 施設が多く残っており，この寺院の特徴のひとつになっている。こ れらの木造架構については, 20 世紀前半のうちに H. パルマンティ エによる復原案が示されたが ${ }^{1}$, 以後, 積極的な議論が少ない。

木造から石造へ至る途上の段階では，木造架構と石材とを接続す るという技術的に特別な状況が現れる。具体的な場面は，石造壁の 上面で起こる，石材と木造梁や垂木を接続するという状況である。 この方法は，その上面に残る痕跡から，きわめて多様な技法が存在 し，年代による変化が認められる。建築全体からみて局所的な現象 であるが，装飾等を持たず年代の手がかりが極度に少ない伽藍の周
辺建物にとって, 編年の指標となる可能性がある。さらに, 建築技 術の歴史的性格を考えるための重要な研究対象であろう。本論考で は，主に石造の壁体上面に残る痕跡に注目し，コー・ケーやプレア・ ヴィヘア寺院を含む同時代の遺構と比較することで技法の発達過程 を素描し，この作業を通じて曖昧であったプレア・ヴィへア寺院の 周辺施設の建立年代について, 可能な限り明らかにしょうとする。

プレア・ヴィへア寺院は, Fig. 1 に揭載したように参道によって 連結される 5 つの施設群から成り立っている。これらは，北から順 に第 5 ゴープラ $(\mathrm{K})$ ，第 4 ゴープラ $(\mathrm{J})$ ，第 3 ゴープラ $(\mathrm{G})$ と その東西の付属施設 ( H, H', I , I '), 第 2 伽藍 (D, C , C', P, $\left.\mathrm{P}^{\prime}, \mathrm{M}, \mathrm{N}, \mathrm{O}\right)$ と第 1 伽藍（A， A'，B，B'，L）およびその東西 の付属施設（E，F）である。このうち第 2 伽藍と第 1 伽藍は接続し ており，全体で山頂伽藍を形成している（建物に付した記号は，パ ルマンティエに倣う)。これらの施設のうち，背面ゴープラ（A）は 迫り出し構造のレンガ造屋根を載せた痕跡を残すが, 中央祠堂 $(\mathrm{B})$, 拝殿 (B'), 第 2 伽藍の 2 つの経蔵 (C, C’), 第 1 伽藍を区画する 回廊 (A') は石造屋根を載せている。そして, その他の施設 (D, E, F, $\left.\mathrm{G}, \mathrm{H}, \mathrm{H}^{\prime}, \mathrm{I}, \mathrm{I}{ }^{\prime} \mathrm{L}, \mathrm{M}-\mathrm{N}-\mathrm{O}, \mathrm{P}, \mathrm{P}{ }^{\prime}\right)$ は，いずれも木造小 屋組の痕跡を残している。

\section{2. 現状と先行研究}

木造小屋組に関する先行研究は限られるが，J. デュマルセによる

\footnotetext{
* 早稲田大学 客員教授・工博

$* *$ 博物館明治村館長, 早稲田大学 名誉教授.工博

*** 早稲田大学理工学術院 准教授・博士 (工学)

**** 名城大学. 早稲田大学調査チーム 調查員・修士(建築学)

***** 早稲田大学大学院創造理工学研究科 博士課程
}

Guest Prof., Waseda University, Dr.Eng.

Director, Open Air Museum MEIJI-MURA, Emeritus Prof., Waseda University, Dr.Eng.

Assoc. Prof., Facuity of Scicnce and Engineerring, Waseda University, Dr.Eng.

Technical Staff, Collaborative Project between National Authority for Preah Vihear and Meijo Univ. and Waseda Univ., M.Arch.

Doctor's Student, Graduate School of Creative Science \& Engineering, Waseda University, M.Eng. 
まとまった提案 ${ }^{2)}$ やこの提案について批判的な検討を加えた澤田知 香, 上野邦一両氏の提案などがある ${ }^{3)}$ 。デュマルセの木造架構の論 考は, パルマンティエの復原案などに批判的な検討を加えつつ提案 されており，瓦の分析からレリーフに描かれた屋根形式の検討，周 辺地域に残る木造架構の類例に至るまで，さまざまな手がかりを網 羅して検討を進めている。とくにカンボジア周辺地域の木造架構の 事例を通じ, クメールの木造小屋組が二重の梁と束によって構成さ れていたとする解釈は，他の可能性を完全に排除できてはいないが 強い説得力を持っている。ただ，個々の遺構の木造屋根の復原案に ついては検討の余地が残された。例えばバンテアイ・スレイ付属建物, タ・プロム付属建物の復原案については, 澤田知香, 上野邦一両氏 による再検討が行われ，適切な修正案が示されている。

しかし先行研究は，いずれも木造小屋組構造の形式をとり上げて 検討したものであって，寺院建築の石造化の過程で，技術的に大き な問題になったであろう石材と木造屋根部材の接続法については, 積極的に検討を加えているわけではない。石材と木材の接続法につ いて技術的解決を模索していった過程の検討は，プレア・ヴィへア 寺院の木造小屋組の復原にあたって最重要な作業であるとともに, それぞれの施設の編年にとって重要な手がかりになりうる。

プレア・ヴィヘア寺院各建物の建立年代を検討するための指標と して, パルマンティエが試みた編年のうち，木造屋根を持つ遺構に 限定して以下に整理する。ただ，パルマンティエは，この編年を仮 説に過ぎないとしている点に留意しておきたい。

1)「ヤショ・ヴァルマンの後継者」の時代 (911-944 頃か)。

・第 1 ゴープラ L，ホール N，第 2 ゴープラ D，第 2 伽藍翼廊 $\mathrm{P}$ 。

2 ） ラージェンドラ・ヴァルマン II またはジャヤ・ヴァルマンV の 時代 (944-1001 頃)。

- 付属建物 E, F。

3 ）スールヤヴァルマン I の時代（1002-1049 頃）

・第 3 ゴープラ付属建物 H, I および H’, I’，第 4 ゴープラ J, 第 5 ゴープラ K，第 3 ゴープラ $\mathrm{G}$ (未完)。

4) ウダヤディティヤ・ヴァルマンの時代（1049-1065 頃）

・第 3 ゴープラ G（崩落した屋根レンガ材の除去）。

5 ） スーリヤ・ヴァルマン II の時代（1113-1149 頃）

・ホールNのポーチ，第 2 ゴープラ D のポーチの改造。

なお，S. サハイによる編年の整理では，第 3 ゴープラ東西の付属 建物を 11 世紀後半とするほかは，木造屋根を持つ建物については積 極的な言及が少ない注 1)。

\section{3．木造小屋組と壁体上部の収まり}

石造壁体上部と木造小屋組の接合法について，私たちが知る最初 の事例はコー・ケーが首都であった時代の遺構である。年代的にみて, この時代以前の建物は，お之らく石造と木造架構が混在する構造は 存在しなかった注 2)。したがってこの時代を䠢矢として混構造が発 生したと捉えられる。以下, 時代に沿ってそれぞれの様相を確認する。

\section{3-1.コー・ケー}

コー・ケーのプラサート・トムの付属建物やプラサート・クラチャッ プのゴープラ付属翼廊では，木造梁を用いるが木造軒桁を持たず， いずれもラテライト造の壁体最上部に載せられた砂岩材に，直接仕 口を刻んで梁を接合している。壁体はいずれもラテライト造を主体

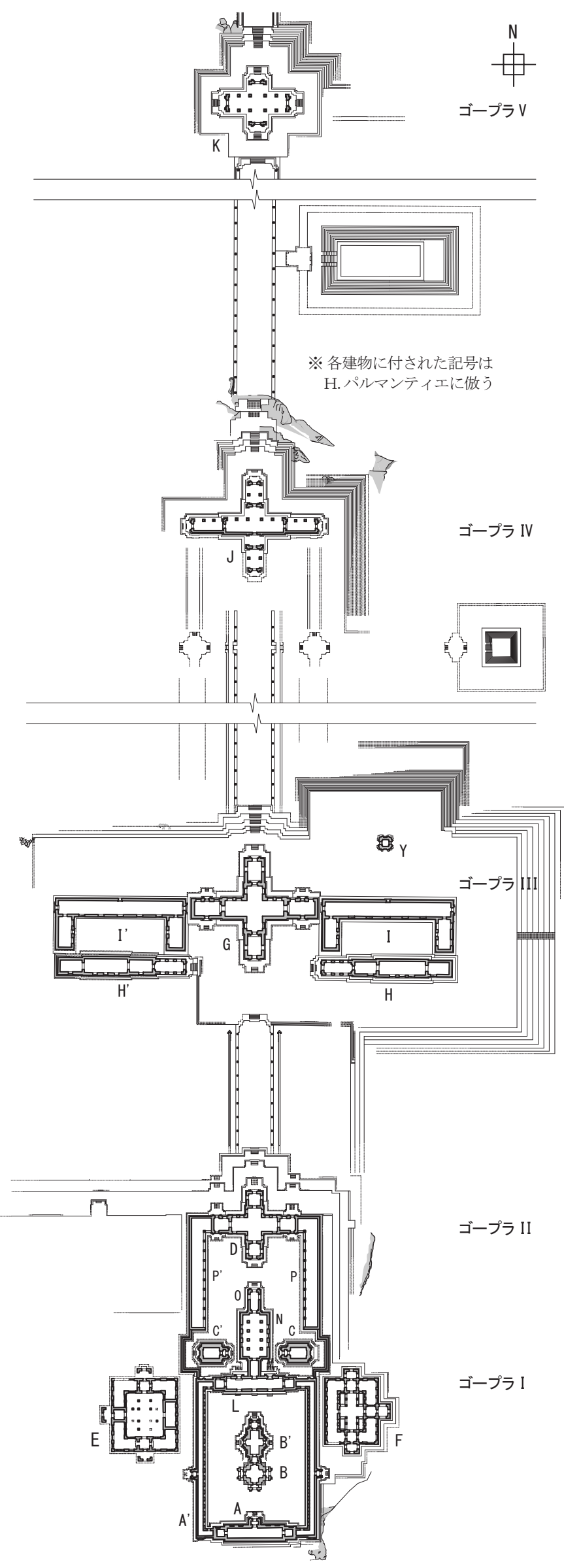

Fig.1 Each Structure Plan of Preah Vihear 
とするが，装飾を施す意図ばかりではなく，複雑な形状の仕口の加 工のためにも, 最上部材に限って砂岩材を採用したのだと考えられ る。この石材の上面は, 木造垂木の下端を引っかけて固定するため の浅い溝を掘り，ここに垂木端を直接当てる仕様である。したがっ て垂木の先端は軒先に踏み出さず, 日本建築の双首のように扱われ る注 3)。Fig. 2-01 はその様相を図示したもので, 左図は複雑な形状 だが「相欠」に類する接合法を持つ。同様の形式は，プラサート・ トム付属施設の複数の建物においても認められる注 4)。Fig. 2-01の 右図は「あり落とし」(ダブ・テイル) 様の仕口で, 妻壁に近接する 梁に限定して使われている注 5)。これらの例は, コー・ケーが首都 であった時代，10 世紀前半（A. D. 928-944 頃）に遡ると考えられる。

\section{3-2. 東メボン, プレ・ルプ}

東メボンの付属建物に見られる木造軒桁は, 壁体上面に沿って石 材の中央に埋め込まれる（Fig. 2-02）。この収まりは，プロポーショ ンにやや相違を持つものの, プレ・ルプの付属建物と同様である (Fig. 2-03)。壁体頂部の石材は, 軒桁の断面に合わせて深く彫り込 まれて凹型の断面を持つ。軒桁の上面は壁体上面と高さを揃え, 垂 木を受けるために露出していたと思われる。一方，軒桁より太い木 造梁は, 壁体や軒桁上面と高さを合わせ, コー・ケーの時代と同様 の位置を維持する。木造梁と埋め込まれた軒桁は石材の内部で接合 される。この接合部は, 敷面の相対的な高さや断面の形状, 梁端の 痕跡の様相などから判断すると, 簡単な「相欠」に類する仕口であっ た。埋め込まれた軒桁は, 梁を固定し垂木を受けるための部材と考 えられるが, 一方, 木造梁は構造材である。このため梁は軒桁より も一段と太い注 6)。したがって軒桁よりも低い敷面をとるから，両 者の接合位置の石材は, やや複雑な形状に加工されている。

3-3.タ・ケオ

一方, タ・ケオの付属建物では, 壁体の上面に軒桁を載せ, 軒先 瓦を被せて並べるよう加工された石材が，軒桁外面に接して設置さ れる。軒桁の敷面と梁の敷面を同一面とするため, 両者の接合位置 の仕口はさまざまに考えられるが, 軒桁の「成」に比して構造材で ある梁の成は, 一段と高かったであろう。確かな痕跡に乏しいが, 梁を下方, 軒桁を上方とする「相欠」様の仕口であったと考えられる。 とすれば, Fig. 2-04に描画したような収まりが予想される。

ところがポーチでは, Fig. 2-05に示したように, 垂木端を収める 浅い溝と瓦を収めるやや深く広い溝が石造横架材の上面に直接施さ れ，さらに梁の端を落とし込む簡単な仕口を設けている。木造の軒 桁を用いず，石材に直接梁と垂木を架ける点は，コー・ケーの遺構 にみられた技法と同様である。

\section{3-4. バンテアイ・スレイ}

バンテアイ・スレイ伽藍中心部の四周に配置された付属建物の木 造小屋組については, 先に述べたように, デュマルセによる天井を 設けたとする復原案に対し, 澤田, 上野両氏が再検討を試み, 改造 が行われたとする的確な復原案が提出されている注 7 )。両氏の復原 案に対し, 補足的な検討を加えたい。

改造痕跡は壁体の嵩上げを伴うもので, 現在のペディメントより も少し背の低いペディメントが存在していた時代が予想されている。 当初の軒桁は, 凹型断面の最上部材（ラテライト）に埋め込まれて いた痕跡を残しており，東メボン，プレ・ルプと同様の収まりであっ た。しかし, 軒桁が収まっていた空隙をレンガで埋めた痕跡が確認

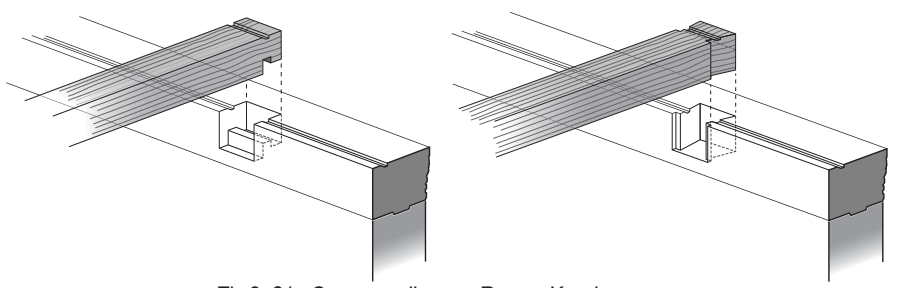

Fig.2-01 Gopura gallery at Prasat Krachap

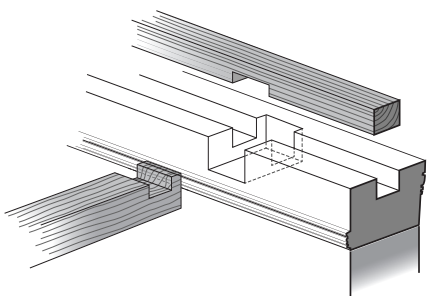

Fig.2-02 Annexed building at East Mebon

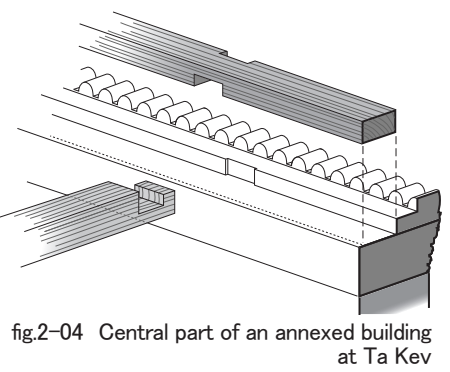

(Before Modification)

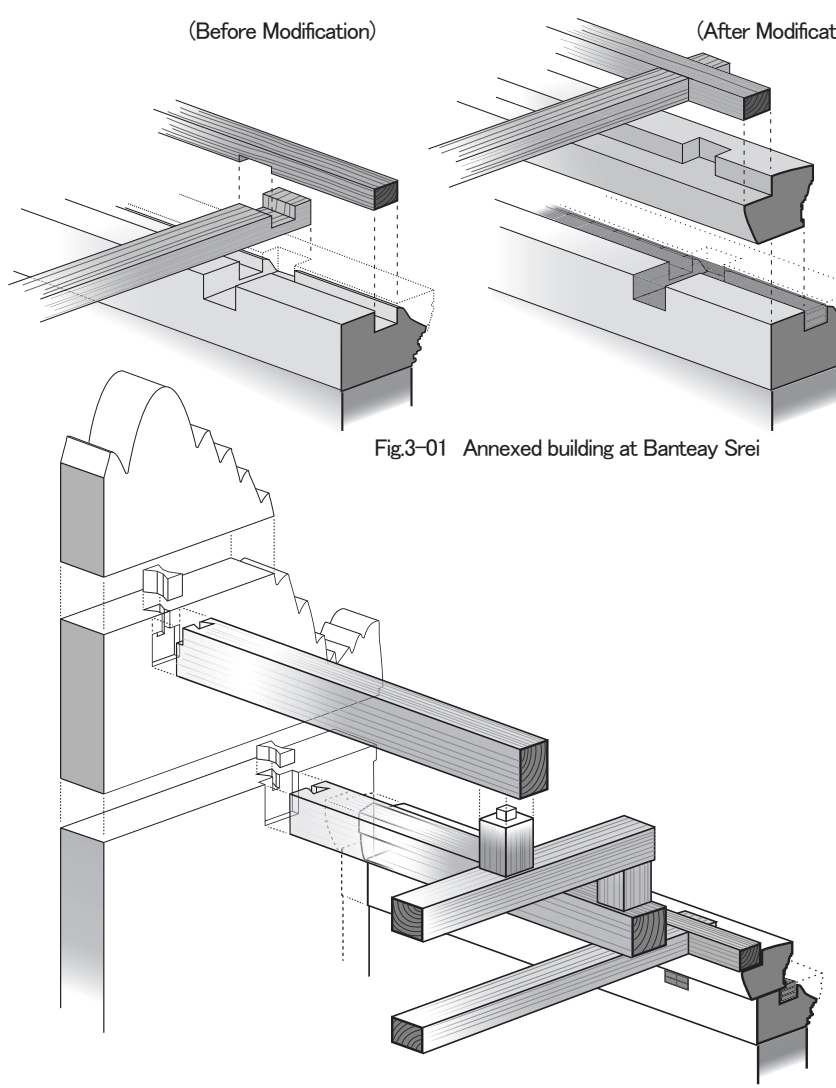

Fig.3-02 Annexed building at Banteay Srei : restoration of the roof frame after modification

されることから注 8), 後の改造時に, 軒桁を取り去ってラテライト 材の外半部を極小の庇屋根の形状に整形したものと考えられる。そ してこの上に, 背の低い腰壁と軒の形状をつくりだした砂岩ブロッ クを重ね, ごく小さな形状だが, 経蔵などにみられる庇屋根を持つ 
姿に改造している。この砂岩ブロックは，削り直された小さな庇屋 根に整合させようとして，やや強引に，室内側でオーバーハングす る不安定な位置に置かれている。このため, 並列するブロックどう しを上面の「契り」で繋ぐ処理が施されている。改造時に積載した この石材は，上部室内側に軒桁を載せる整形が施されており，全体 として太いL字型の断面を持っている。タ・ケオの付属建物では, 独立した別形状の石材を外側に据えるが，外側を立ち上げた石材の 上面に軒桁を置く点で同様の技法であり，改造前の痕跡にみられる， 軒桁を石材に埋め込む技法とは異なっている。

改造後の梁の痕跡は，残存状態が悪く確認できないが，改造過程 で当初の軒桁が位置を変えているから，軒桁と接合する仕口を持っ た梁だけが当初の位置に残ることは考え難い。したがって改造前と 同位置の直上に，あらたに架け直されたと考えられる（Fig. 3-01）。 軒桁の上面高さは，およそぺディメントに残る母屋桁の大入れ痕跡 の下端に当たるため，その間に渡される梁は軒桁と上面を揃えてい たと考えられる。これは夕・ケオの事例などと同じ収まりである。 同時にこのことは，梁上に束を用いず，母屋桁を直接載せた小屋組 であったことを意味する。(Fig. 3-02)。

建物隅に位置する壁体上部のラテライト材も，当初材の軒桁を受 けていた痕跡を残している。改造後に屋根型に削られ変形している が，それでも当初の軒桁が妻側に突き抜け，木口を見せていた痕跡 が認められる。これは東メボンやプレ・ルプの妻側に見られる痕跡 と同様で，軒桁の木口と木造の破風板が接合していたことを予想さ せる。Fig. 4-01 はプレ・ルプの付属建物に見られる痕跡と，破風板 との収まりを推定した図である。Fig. 4-02 は東メボンの壁体上部の 砂岩材にある妻側の痕跡である。身舎上部のいずれの砂岩材も，軒 桁が突き抜けていた痕跡と, その下部に破風板下端を載せた突出部 がみてとれる。木造破風板の形状については不明だが，この突出部 の形状から石造に置き換えられた姿と極端に異ならなかったと予想 される注9)。破風板が木造で壁体上面に木造桁が埋め込まれた痕跡 を残すから，妻壁も木造であったと予想される注 10)。したがって， バンテアイ・スレイ付属建物の当初ペディメントも木造であった。

現在の石造妻壁には母屋桁の浅い大入れ跡が残り，大入れ痕跡の 中に「契り」を用いた痕跡を残している注11)。この痕跡は，すべて ペディメントを構成する石材上面の水平目地に合わせて施設される から，母屋桁の高さに合わせて石材ブロックの高さを調整し，妻壁 の石材と母屋桁とを交互に組むという作業過程が予想される。契り の採用は，妻壁が薄く，大入れの仕口が浅いことに起因する工夫で あったと指摘されているが3)，当初，木造妻壁に合わせて下部の壁 体を比較的薄くとったため，改修後の石材ペディメントに十分な厚 さをとれなかったことに起因すると考えられる。したがって一連の 改造は，主に木造ペディメントを石造化しようとするものであった。 その過程で軒桁の収まりの技法に変化が現れている。技法の特徵か ら見て, この改造は, タ・ケオ付属建物の時代とそれほど離れない 時代に行われたと考えられる。

\section{4. プレア・ヴィヘア寺院の木造屋根に見られる軒桁と梁の様相} 4-1. プレア・ヴィヘア第 1 , 第 2 ゴープラ, 建物 H， ホールN

夕・ケオ付属建物の身舎（Fig. 2-04）によく似た収まりは，プレ ア・ヴィヘアの第 1 ，第 2 ゴープラにも見られる。これらの建物では，

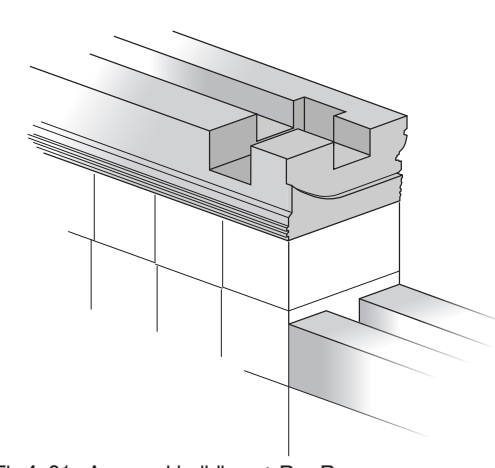

Fig.4-01 Annexed building at Pre Rup: Traces of eave girders and wooden gable
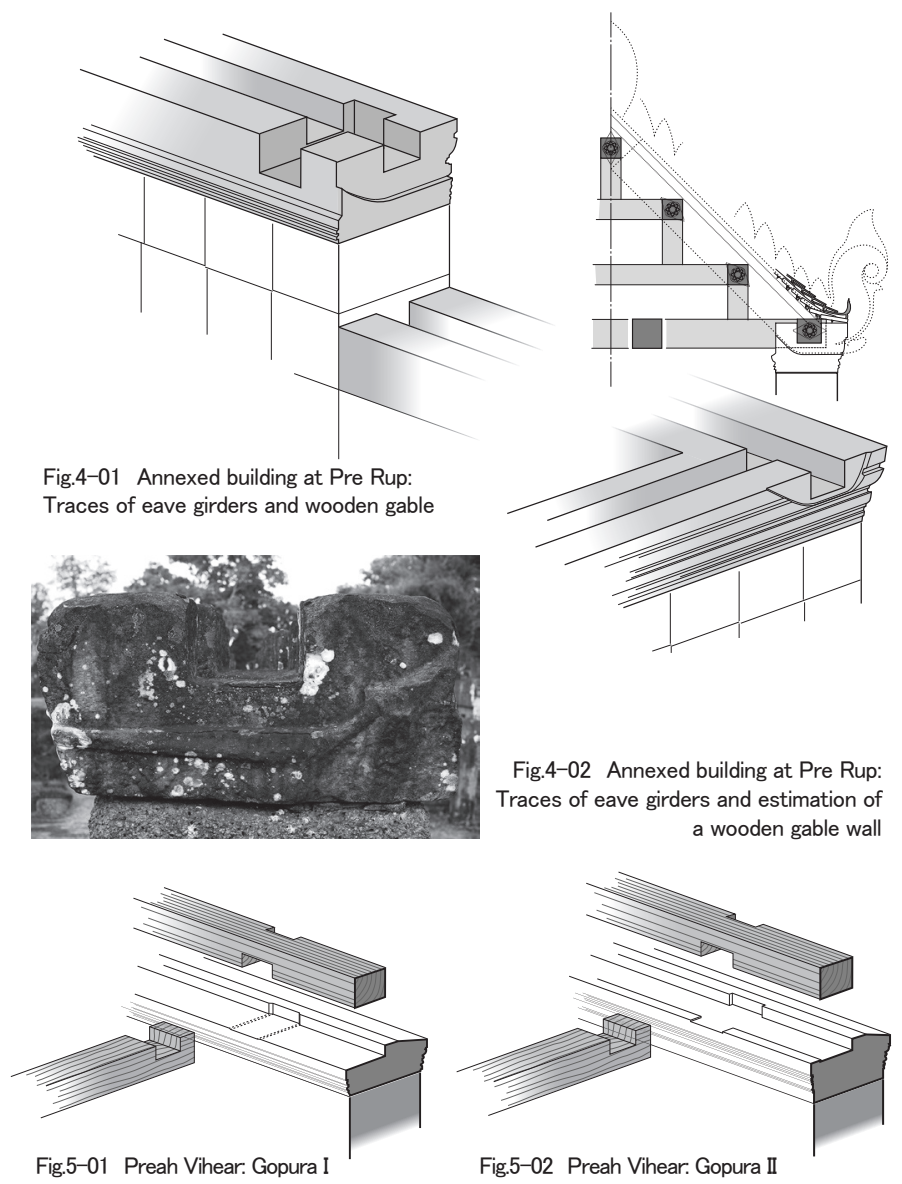

Fig.5-02 Preah Vihear. Gopura II
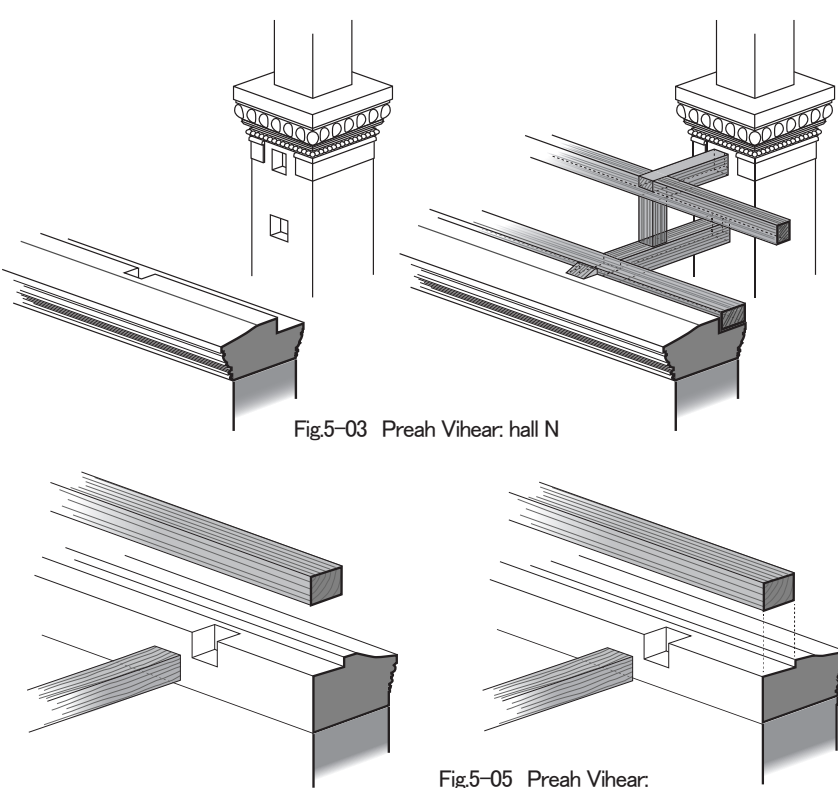

Fig.5-04 Preah Vihear. Building E

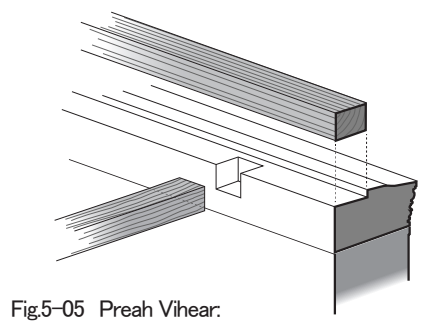

Fig.5- 05 Preah Vihear.
Annexed building $\mathrm{H}^{\prime}$ on west side of Gopura III

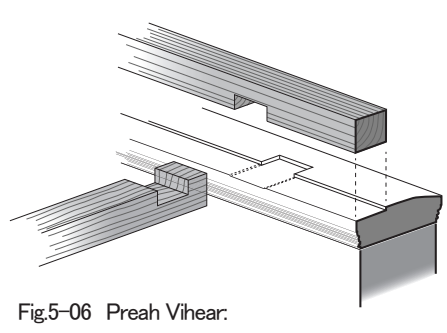

Annexed building I' on west side of Gopura III

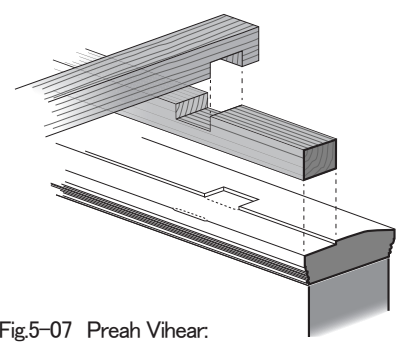

Annexed building I on east side of Gopura III 
軒先の石材の立ち上がりが低く軒先瓦の形状も持たず，上面は外に 向かって緩やかに下る勾配をとっている（Fig. 5-01，02）。勾配を持 つ外半部の上面は仕上げが粗く, 別の石材を載せた形跡がないから, おそらく，短い軒垂木等を直接並へ，この上に焼成の軒先瓦を載せ ていたようにも思われる。いずれも軒桁と梁の敷面を同一高さとす るが，よく観察すると木造梁の輪郭に合わせて敷面をわずかに沈め ている個所が認められることから,梁を下にして軒桁を被せた「相欠」 様の接合であったとみられる。

第 2 伽藍のホール N の壁体上面の収まりも，第 1 ，第 2 ゴープラ などと同様で，軒桁を内面に合わせて配置するよう削りとられた砂 岩材を最上部に載せている。梁の端を収めた痕跡は第 2 ゴープラに 比べて大きく，軒桁と梁が簡単な「相欠」様の仕口で接合されてい たことを予想させる。敷面は，ポーチで梁の敷面をやや沈めた痕跡 があり，第 1 ，第 2 ゴープラと同様に，梁を下に敷き軒桁を被せた 接合法を予想することができる（Fig. 5-03）。

\section{4-2. 建物 $E$}

建物 Eでは，軒桁を壁体上面に載せ，梁は壁体上面に梁上端が位 置するよう石材に直接架ける。したがって梁の位置は，軒桁に対し 梁成ひとつ分下に位置する。石材はコー・ケーのような仕口を持た ず，タ・ケオ付属建物のポーチの梁の収まりと同様で，軒桁は，梁 の端を上から抑えるように積載される（Fig. 5-04）。したがって軒桁 と梁は上下に重なり接することになるが，直接的な接合がなかった か，あるいはダボなどを用いて接合していたであろう。

\section{4-3．第 3 ゴープラ付属建物}

第 3 ゴープラ付属建物は，一見して東西いずれも「口の字」平面 の建物にみえるが，南辺に位置する「一の字」平面の建物と他の三 方の辺を構成する「コの字」平面の建物とで構成されており，2つ の建物の基壇は突きつけて接するから，同時に造営されたものでは ない。構成は，まず「一の字」平面の建物が建ち，後から中庭を囲 む「コの字」平面の建物が接続されたと考えられる。この施設は第 3 ゴープラを挟み，対称性を以て東西に配置される。

2 つの付属建物は，よく似ているが細部がかなり異なっている。 とくに西建物のうち「一の字」平面建物（H’）は，後に東端ポーチ を増築し，同様の改造を西端でも行った。西端は，連子空を含んで 端まで増築されたが，背面は未完成のままである。

西「一の字」平面建物（H’）の前身は建物中央部に残っており, 確認できる範囲が限られるが，壁体最上部の砂岩材の仕口跡から， 軒桁から 1 段下げて梁を架けていたことが判る（Fig. 5-05）。この技 法は建物 $\mathrm{E}$ と同様である。しかし西「コの字」平面の建物（ I ’ ）で は，軒桁と梁が同一の敷面上で接続する。ただ，砂岩材の敷面を観 察すると，梁が載った位置で，梁の輪郭に合わせて軒桁の敷面より もわずかに沈めた痕跡が認められる箇所があるため，梁が下に，軒 桁が上に位置する「相欠」様の接合であったことが判る（Fig. 5-06）。

東側の付属建物のうち，「一の字」平面の建物（H）の壁体上面の 軒桁の敷面でも，同様に梁位置を軒桁敷面よりもわずかに沈めてお り，梁が下に軒桁が上に位置した接合であった。しかしポーチにつ いては様相が異なる。ポーチ上部では，2つの砂岩材に跨がってつ くり出された奇妙な仕口（背の低い矩形が敷面から作り出される） が認められる。これは空間小壁の上で，石造の横架材どうしを，軒 桁を用いて繋ごうとした簡単な仕口の形状だと考えられる。したがっ
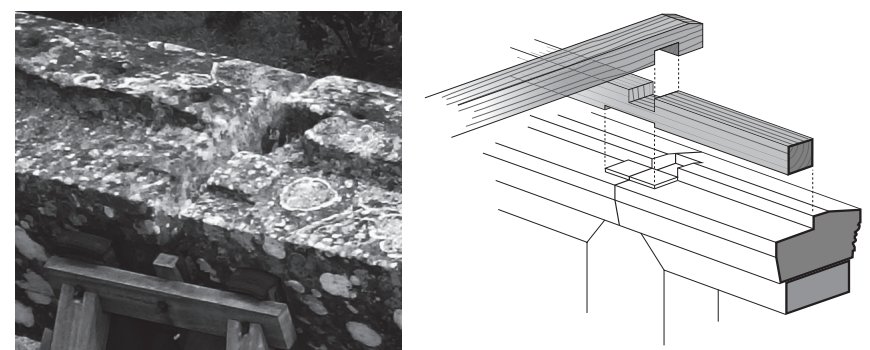

Fig.5-08 Preah Vihear.

Traces at the top of the wall in Porch of building $\mathrm{H}$ on the east side of Gopura III
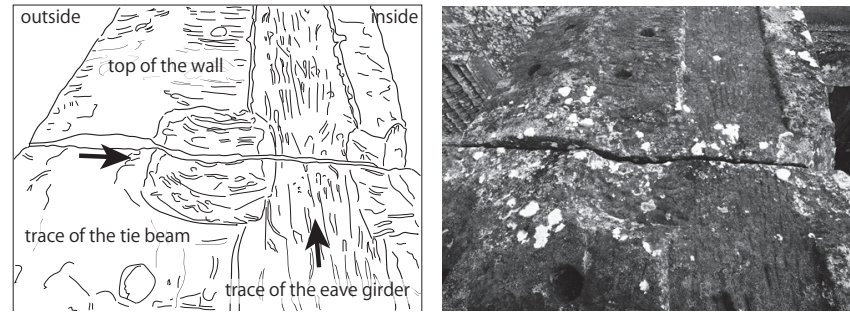

Fig.5-09 Preah Vihear. Annexed building I on east side of Gopura III
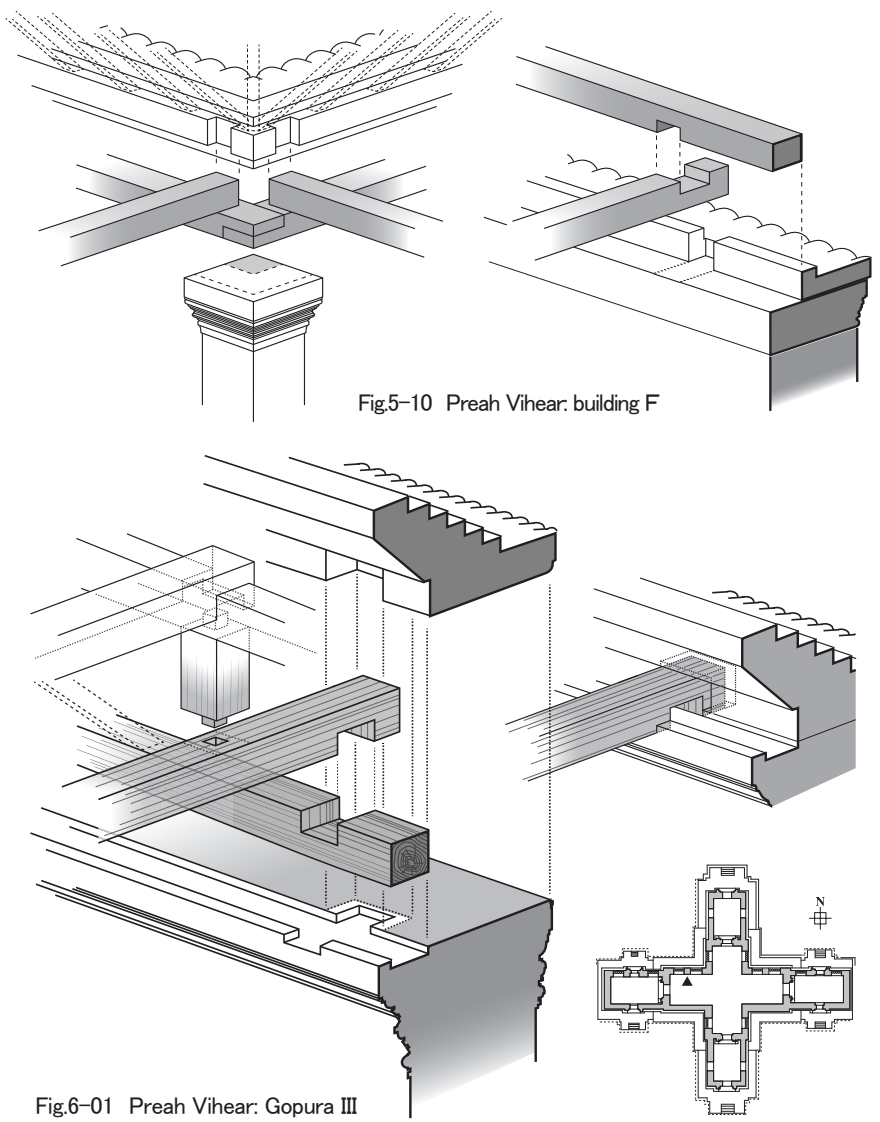

Fig.6-01 Preah Vihear: Gopura II

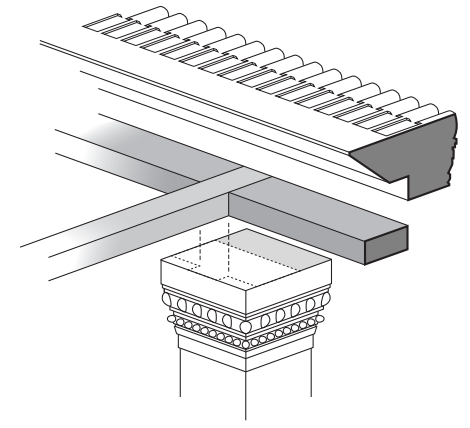

Fig.6-02 Preah Vihear: Gopura IV

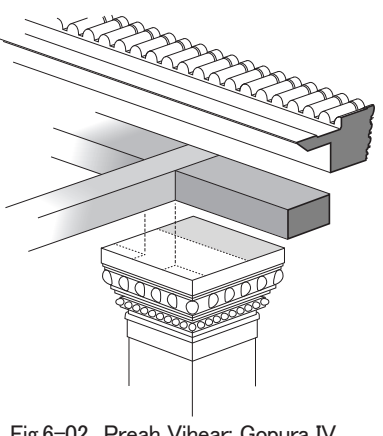

Fig.6-03 Preah Vihear: Gopura V 
て軒桁は，敷面およびつくりだした仕口に直接載ることになるから， 木造梁は軒桁に対し上から接合したと考えるほかはない。東「一の字」 平面建物（H）のポーチでは，例外的に軒桁が下，梁が上という関 係をとる（Fig. 5-08）。一方，東「コの字」平面建物（I）の敷面の 状態は，反対に，梁と軒桁が交差する位置の敷面で，梁端が載る敷 面がわずかに沈み，両者が交差する位置で，軒桁の敷面高さが維持 される例がみられる（Fig. 5-09）注 12)。したがって, Fig. 5-07 に示 したように梁が上，軒桁が下に位置する接合であった。

\section{4- 4. 建物 F}

建物 $\mathrm{F}$ の外壁上部では，軒桁と梁が敷面を同じくして接合された と見られるが，一部で梁の輪郭に合わせて軒桁敷面よりわずかに沈 めた痕跡が残っている。したがって梁が下, 軒桁が上に位置する「相 欠」様の接合が予想される。中庭に建つ石柱の上に木造桁の上面に 梁を載せた痕跡が残り，木造桁は石造横架材の下部内側に施設され る。一方, 外壁上部では, 石材が軒桁の上面を覆った形跡は認めら れない。Fig. 5-10 は，外壁上面の様相とともに，中庭の隅柱上の軒 桁と梁の様子を復原したものである。中庭の独立柱上に載る, 一見 して軒桁ともみえる部材は, 梁よりも 1 段下という異例の位置に置 かれるが，この位置では低すぎて垂木端を収めることが難しい。し たがって, 独立柱上に載る木造桁は, 軒桁ではなく石造横架材を支 持し補強するための桁と考えなければならない。また垂木は，石造 横架材の上部内角を削り，ここに直接掛けていたと考えられる注 13)。

\section{4-5. プレア・ヴィヘア第 3，第 4，第 5 ゴープラ}

プレア・ヴィヘア第 3 , 第 4 , 第 5 ゴープラでは，軒桁側面ばか りでなく上面を，垂木の下端も含めて高い位置で覆うように加工さ れた石材が認められる（Fig. 6-01，02，03）。この収まりは，現存 する石材の積載の様相からみて, 壁体上面を加工して軒桁を設置し, さらに垂木を固定した後, 軒瓦型を持つ石材を被せるように施設す るという手順が予想される（Fig. 6-01）。第 1，第 2 ゴープラ，建物 Eなどの考え方とは大きく異なっている。また，いずれのゴープラ も太い十字形平面を持つため, 軒桁の中間は，平面中央の交差部で 中空に架かるから，この位置で梁の役割を担う。このため軒桁と梁 は同一の部材となり同一の高さに架かる。軒桁と梁は性格が異なる ため太さに差がみられたが，この段階では部材としての相違が消失 すると考えてよい（Fig. 7-01，02）。したがって隅部では同一材が交 差するから，いずれが上か下かは問題にならないが，場所によって 比較的明瞭な痕跡が残っており（Fig. 7-03）, 南北方向の軒桁を架け, 次に東西方向の軒桁を被せる手順であったことが判る注 14$)$

軒桁と梁の接合部を載せる石材の敷面は，3つのゴープラのいず れもよく整形され痕跡が明確ではない。しかし, 微かに残る形跡から, 軒桁に架かる梁は, 「相欠」様の仕口が開かない上うに軒桁を下に置 き上から被せて接続したとみられる注 15$) 。$ 先に述べた第 3 ゴープラ 東付属建物 Hの出現以後, 軒桁と梁の収まりが逆転するという技法 の推移が認められる。

\section{4-6. 技法の整理}

プレア・ヴィヘア寺院の木造屋根の遺構を検討するため, 他の事 例を集めて軒桁と梁の様相について検討を試みた。壁体上部に施設 された木造梁と木造の軒桁を巡る様相は，以上に詳述したように， 時代によって多様な変化を見ることができる。

壁体上部の石材に直接仕口を施し，木造梁を架けようとしたコー・
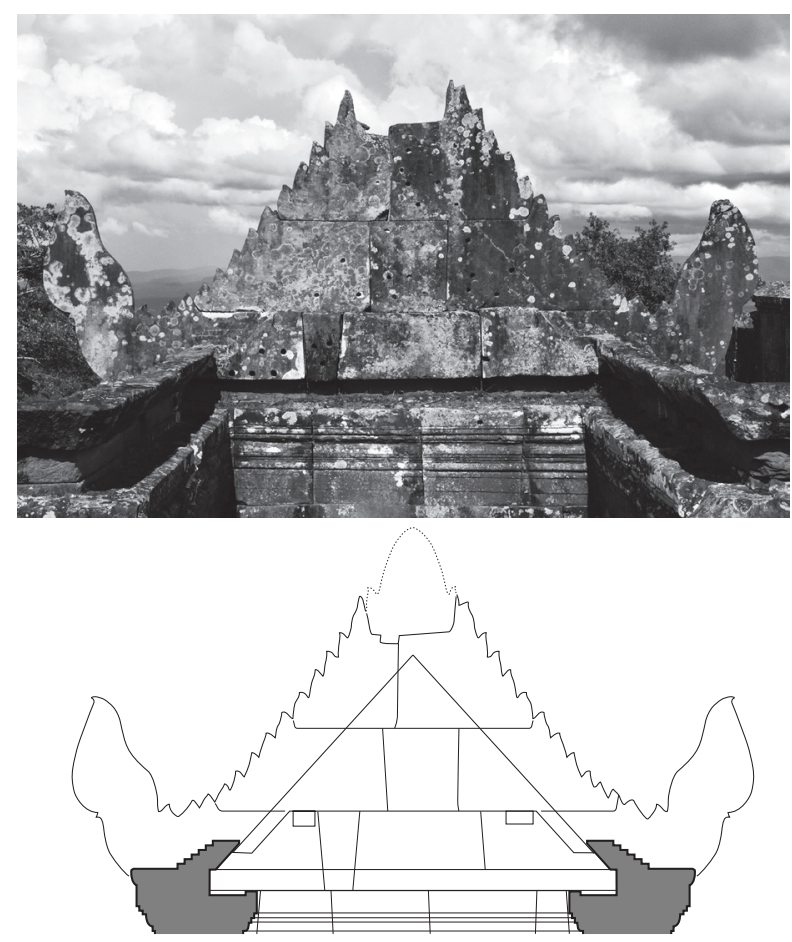

Fig.7-01 East pediment of the central chamber of Gopura III (main chamber side)

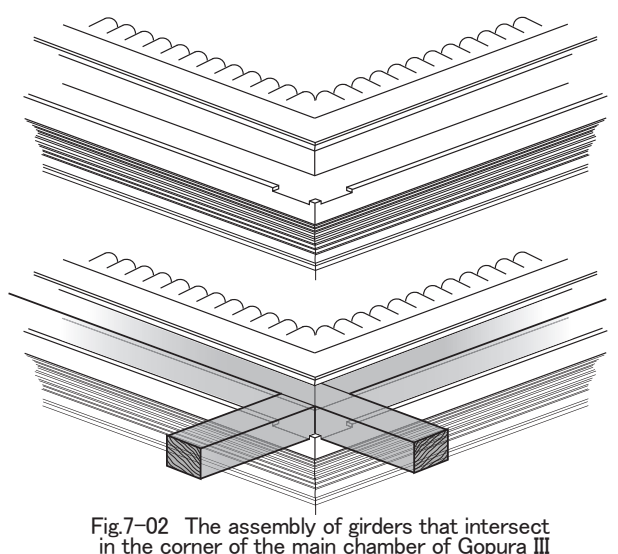

in the corner of the main chamber of Gopura III

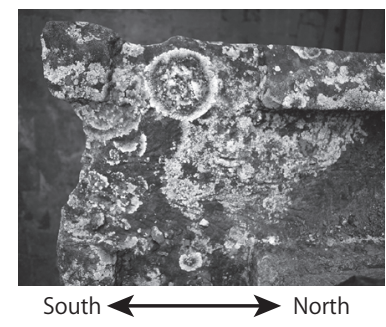

Fig.7-03 Traces on corner at the top of the wal in main chamber on the east side of Gopura III

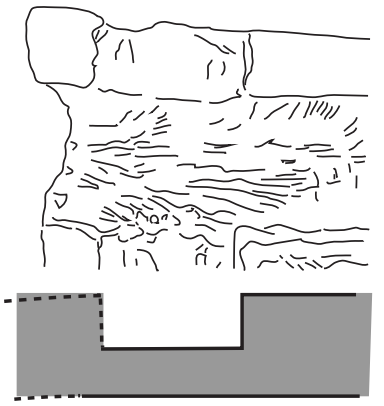

ケーの事例を嚆矢とし, 東メボン, プレ・ルプ, 改造前のバンテアイ・ スレイ各付属建物の事例は, 木造の軒桁が現われたことを示してい る。これは垂木端を確実に固定することを目指した工夫で，上面を 見せて石材に完全に埋め込む収まりであったと思われる。木造梁は 構造材であるため軒桁よりも一回り大きな断面を持つが，軒桁と上 面を揄えて施設された。石材の痕跡は，梁が下から軒桁と噛み合う 「相欠」様の仕口が存在したことを物語っている。しかしこの後, タ・ 
ケオ，プレア・ヴィヘアの第 1 , 第 2 ゴープラ，ホール $\mathrm{N}$, 第 3 ゴー プラ付属建物 $\mathrm{H}^{\prime}, \mathrm{I}, \mathrm{E}$ などでは, 軒枌は壁体上部に据えられ, 外 側面に石材が置かれる（あるいは石材に段差が設けられて外側を高 くとる）という収まりに変化する。つまり，木造軒桁の上面だけで

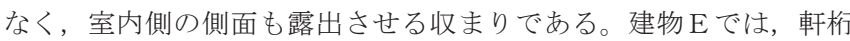
は壁体上面に載るが，梁は壁体最上部材の大入れの仕口に上端を揃 えて挿入される。両者は梁の高さ分の段差を持ち, 梁が下方に位置 する。この収まりは第 3 ゴープラに付属する西の「一の字」建物 (H’) の前身部分にも認められた。他の例はいずれも軒桁と梁の敷面の高 さを同一とするが，一部で梁の敷面をかすかに沈めようとした痕跡 が認められたことから，上方の軒桁に下方から梁が接続する「相欠」 様の仕口が予想された。部材の上下関係を示唆する痕跡がみいだせ ない夕・ケオ付属建物や痕跡を消失している改造後のバンテアイ・ スレイも，おそらく同様の収まりであったと考えられる。

しかし，第 3 ゴープラ東付属建物の「コの字」建物（I）および 第 3 , 第 4 , 第 5 ゴープラでは，軒桁と梁の敷面高さを同一としな がら, か寸かに残る痕跡から，軒桁を下方に，梁を上方に置く接続 であったことが判る。また，軒桁上に梁を積載する建物 F の中庭独 立柱上では，軒桁の上に，たんに木造梁を載せた事例も認められた。 さらに，第 3 ，第 4 ，第 5 ゴープラでは，壁体上面に軒桁を施設し て外側面に石材を置き，軒桁に固定される垂木の下端を含め，軒桁 上方を，空隙をとって石材で覆うようになる。

\section{5. 壁体上部の収まりの変遷過程と技法の編年}

石造の壁体と木造梁，木造軒桁のさまざまな収まりについて，可 能な限りそれぞれの時代の特定を行いたい。

木造の軒桁を持たないコー・ケー, プラサート・トム付属建物, プラサート・クラチャップのゴープラ翼廊の事例は，コー・ケー首 都時代, ジャヤヴァルマン 4 世とハルシャヴァルマン 2 世 (928-944) の時代と判断される。この技法は，石造と木造の接合法として石材 に精緻な仕口を刻むが，簡単な溝を掘る垂木との接合法が粗略であ る（Fig, 2-01）。クメールの屋根荷重を支持する垂木の下端は双首の ように収まるため，石材上面に確実に接合できず外れることがあれ ば，おそらく大量の瓦の落下を伴って屋根の崩落を招いたであろう。 垂木の接合を確実にするためには，壁体上面に木造部材が必要に なるとともに，その木造材が壁上で確実に固定されることが必要に なる。このための工夫は，木造軒桁を壁体上面に埋め込む東メボン， プレ・ルプ，バンテアイ・スレイ付属建物（改造前）に見られる技 法である（fig, 2-02, 03, 04)。この方法は，軒桁を壁体最上部石材に 上面を揃えて完全に埋め込むが，軒桁を用いなかった前時代の形状 を踏襲しつつ，軒桁，梁，垂木など木材どうしの強固な接合を実現 することを目指したためと考えられる。仕口は木材どうしで刻むか ら，石材加工にそれほど䋊細な作業を求めずにすみ，軒桁と梁，軒 桁と垂木の接合も容易かつ確実になったであろう。

垂木端は確実に固定できるようになったと思われるが，凹型断面 の石材に軒桁を埋め込んだため，漏水が溜まることで，軒桁の腐朽 を促すことになったと思われる。これら 3 遺構は, いずれもラージェ ンドラヴァルマン 2 世 (944-968) の時代の建築で，事例のうち最も 早い東入ボンが 952 年の建立と考えられているから，木造軒桁を導 入し，壁体最上部の石材に埋め込むという工夫は，10 世紀後半に入
る頃に現れたと考えられる。

上記の方法に対し，タ・ケオ，プレア・ヴィヘア第 1 , 第 2 ゴープラ, 第 3 ゴープラ付属建物西「コの字」平面建物 H’ , 東「一の字」平 面建物 I などにみられる方法は, 軒桁を埋め込まずに壁体上部に積 載し，外面を石材で保護するという方法をとる。このため相対的に 漏水が留まり難く乾燥しやすい（fig. 2-04, fig. 5-01, 02, 06, 07)。お そらく先行する東メボン，プレ・ルプの方法の改良版であった。こ の時代はジャヤヴァルマン 5 世の治世（968-1000 頃）に該当する。 ただ，壁上に軒桁を載せて外面を石材で覆うため，壁体上面を基準 とすれば，コー・ケーの時代よりも軒がやや高い位置をとる。タ・ ケオの付属建物では, 独立柱上に石造横架材を架けるポーチに限っ て木造軒桁を用いず，石材上面に直接垂木と瓦を施設した痕跡を残 している（Fig. 2-05）。柱上に石造横架材を載せるため，上部に厚み が出ることを避けたのであろう。不明な点も残るが，改造後のバン テアイ・スレイ付属建物もこの時代に属すると考えられる注 16)。

上記の技法は，軒桁と梁を同一敷面上で接合するが，いずれも前 時代の名残を受けて梁を下方，軒桁を上方とする「相欠」様の仕口 である。それでは，プレア・ヴィへアの建物 E (Fig. 5-04)，第 3 ゴープラに付属する西の「一の字」建物（ $\mathrm{H}^{\prime} ）$ の中央部（前身建物） (Fig. 5-05)，タ・ケオのポーチ様の石材に直接梁を架けながらも壁 体上に軒桁を載せるなどの技法は，どのように捉えればいいだろう。 同様の事例が少なく考えにくいが，木造梁は，複雑な仕口を刻ま ずに壁体最上部石材に直接接合している点が，コー・ケーや東メボン， プレ・ルプなどの付属建物に共通する。しかし軒桁を石材に埋め込 むのではなく壁体上面に載せる点は，東メボン，プレ・ルプの技法 よりも新しい。とはいえ, タ・ケオ付属建物, プレア・ヴィへア第 1 , 第 2 ゴープラなどのように，木造梁が壁体の上で軒桁と同一敷 面の位置まで上らず，壁体と上面を揃える位置に留まっている点は 古風である。したがって, 建物 $\mathrm{E}$ の時代はジャヤヴァルマン 5 世の 治世（968-1000 頃）の後半の時期と考えられる注 17)。この時代の末 期，およそ 1000 年頃に建立されたタ・ケオ付属建物のポーチの技法 も，軒桁は用いないが梁の収まりが共通している。

プレア・ヴィヘア第 3 ゴープラ付属建物（西H’， I’，東H，I） の 4 つの建物は，梁上面を壁体上面に揃える西「一の字」平面建物 （Fig. 5-05）と軒桁，梁の敷面高さを揃え，梁を下，軒桁を上とする 仕口を持つ西「コの字」平面建物（I’）（Fig. 5-06）および東「一の 字」平面建物 $(\mathrm{H})$, そして同様だが軒桁と梁の上下が逆転する東「コ の字」平面建物（I）（Fig. 5-09）の3 種類であった。このうち東「一 の字」平面建物は, 碑文から 1026 年頃までに建立されたと考えられ ている。したがって，スールヤヴァルマン一世（1002-1050）の治世 中頃の建築である。おそらく時間を置かずに，対称性を保つため西 「一の字」平面建物に改造と増築が施されたと思われる。前身建物は, 先に記したように 10 世紀の第 4 四半期頃と考えられる。

西「コの字」平面建物（I'）と東「一の字」平面建物（I）には木 造架構の技法に差が認められないから, 西「コの字」平面建物 (I’) は, 西「一の字」平面建物（ $\mathrm{H}^{\prime}$ ') の増改築後, それほど遅くない時期 に建立されたと考えてよさそうである。しかし東「コの字」平面建 物（I）は, 木造架構の技法からみて, 一段と時代が下ると考えられる。

プレア・ヴィヘア第 3 ，第 4 ，第 5 ゴープラ（Fig. 6-01，02，03） に見られる顕著な特徵は 3 点ある。第 1 は壁体上面で接合する軒桁 
と梁の関係が逆転し，梁が上に位置する仕口に変化することである。 これは，屋根荷重を受ける梁の変形を考慮すると，仕口が口を開け ないよう梁を上から被せた「相欠」は，梁の垂下を抑制するように 働くから，構造的により安定する接続法へ移行したものである。こ の工夫は, 第 3 ゴープラ東「コの字」平面建物（I）を除き，プレア・ ヴィへアの他の遺構の木造痕跡には見られない。

第 2 に，軒桁と個々に接続される垂木の下端を含め，上部を石材 で覆う工夫が見られる。建物 $\mathrm{F}$ および第 4 , 第 5 ゴープラをみると, 独立柱の間に架け渡された石造部材の底に，木造梁が一部入り込ん

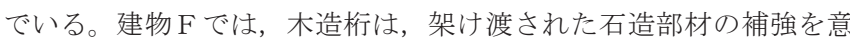
図した部材とみえるが，第 4 ，第 5 ゴープラでは軒桁の機能をかね

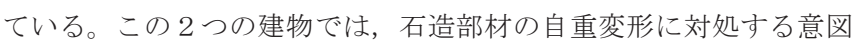
も含まれるように見えるが，そのような意図だけであれば，壁体だ けで構成される第 3 ゴープラに同様の工夫が現れる理由がない。し たがって軒桁上部に石材が被るようになる工夫は，軒栴が壁体上面 に載るようになってのち，上部の漏水が軒桁にかからないよう保護 する工夫が一段と進んだ結果と考えられる。木造軒桁を使わない時 代から軒桁を埋め込む時代を経て，軒桁が壁体上面に載せられるよ うになった一連の工夫の過程からみて，軒桁の腐朽を促す漏水に対 し，一貫して対処しょうとしてきた結果と考えることができる。

第 3 に, これら 3 つのゴープラはいずれも太い十字平面を持つが, この平面形式では，独立柱や壁体の上部に載った軒桁は，交差部で 中空に跨がる梁の役割に変化する。したがって軒桁と梁は同一断面 の部材となり, 先行する時代のように, 軒桁が細く梁が太いという 部材の相違が消失する。

以上の特徵から, 建物 $\mathrm{F}$ は, 建物外壁上部の軒桁と梁の収まりを みる限り，外壁上では軒桁と梁の敷面高さが揃ってはいても，まだ 梁を下に，軒桁を上にする仕口が認められること，また中庭の独立 柱の上で，木造梁が木造桁上面に仕口を持たずに積載されるが，こ の桁は，石造横架材の補強のために石造横架材の下端に挿入された もので，垂木は石造横架材の上部に直接掛けられている。独立柱を 持つ第 4 , 第 5 ゴープラでは，垂木を受ける軒桁が，石造横架材の 補強の役割も担っており, さらに軒桁と梁とが同一の部材として扱 われる。建物 F では，まだこのように整理された状態がみられない。

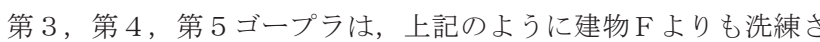
れた木造架構を持っている。これらの特徵は，いずれのゴープラも， 早くともスールヤヴァルマン一世時代の後末期以後の造立であり, 建物 $\mathrm{F}$ との技法上の距離を考えれば，おそらく 11 世紀後半以後から 12 世紀に至って造立されたことを示唆している。

以上の考察を編年としてまとめると以下のようになる注 18)

1 ）ジャヤヴァルマン 4 世 (928-941) 頃 : プラサート・トム付属建 物, プラサート・クラチャップゴープラ翼廊

2 ） ラージェンドラヴァルマン 2 世 (944-968)・10 世紀第 3 四半期 : 東メボン, プレ・ルプ, バンテアイ・スレイ付属建物（改造前）

3 ）ジャヤヴァルマン 5 世 (968-1000 頃)・10 世紀第 4 四半期 : バ ンテアイ・スレイ付属建物（改造後），タ・ケオ付属建物，プレア・ ヴィヘア西「一の字」平面建物の前身 ( $\mathrm{H}^{\prime}$ 中央部)，建物 $\mathrm{E}$,

$4 ）$ スールヤヴァルマン 1 世 $(1002-1050) \cdot 10$ 世紀末〜 11 世紀第 1 四半期：プレア・ヴィへア第 1 , 第 2 ゴープラ，第 3 ゴープ ラ付属建物西「コの字」平面建物 I , , 東「一の字」平面建物 $\mathrm{H}$,

\section{建物 F}

5 ) スールヤヴァルマン 1 世 (1002-1050)・11 世紀第 2 四半期: プレア・ ヴィヘア東「コの字」平面建物 I

6 ） ウダヤディティヤヴァルマン 2 世（1050-1066）以後・11 世紀 後半〜 12 世紀 : プレア・ヴィヘア第 3 , 第 4 , 第 5 ゴープラ

上記に記したように，編年は 6 期に区分されるが，いずれも上限 の時期を想定したものである。技法の変遷は古い技法と新しい技法 とが併存する時期がある可能性も考慮に入れる必要がある。また， 第 4 期までに比べ，第 5 期は，スールヤヴァルマン 1 世の時代以後, どの王の治世に相当するかは明確ではなく，これも上限の時期を想 定したものである。このため第 6 期はさらに時代が不明瞭であり, いずれも大きく時代が下る可能性も残される。

\section{6. むすび}

石造の壁体や独立柱の上に木造屋根を載せることは, 技術的に容 易なことではなく，両者を確実に接続する方法はさまざまに工夫さ れた。その過程は, 上記のように, 木造梁をどのように接続するか という問題を含みながら, 垂木を受ける木造軒桁の発生と腐朽を防 ぐ工夫など，複合的な発達過程を辿ったと考えられる。その過程は， およそ一世紀を超えて進展したが, その後, 伽藍の全建築が石造屋 根に置き換わっていった。

比較的短期間に次々に多様な工夫が現れたが，その様相からプレ ア・ヴィへア寺院の各遺構のおよその編年を読みとることができる。 この局所的な技法に限定してみる限り，パルマンティエによって推 定された第 1 ゴープラ $(\mathrm{L})$, ホール $(\mathrm{N})$, 第 2 ゴープラ $(\mathrm{D})$, 第 2 伽藍翼廊（P， P'）の建立年代，つまり「ヤショ・ヴァルマン の後継者」の時代（911-944 頃か）は, 石造壁体上に木造軒桁を置 くというアイデアがまだ生まれていない時代であり, この時代に続 く東メボンやプレ・ルプの付属建物に見られる技法とも異なってい る。この工夫は, 早くとも 10 世紀の第 4 四半期から 1000 年頃の技 法であり，西「一の字」平面建物（ $\left.\mathrm{H}^{\prime}{ }^{\prime}\right)$ の前身建物や建物 $\mathrm{E} の$ 方 がやや古い技法であることが判る。また第 3 ゴープラ付属建物は, 同時代に一度に造営されたものではなく, 碑文（K381）から東「一 の字」平面建物 $(\mathrm{H})$ の建立を 1026 年と見れば，それ以前の西「一 の字」平面建物 ( $\left.\mathrm{H}^{\prime}{ }^{\prime}\right)$ の前身建物, 同時期の西「コの字」平面建 物（I ')，そして時代が下る東「コの字」平面建物（I）という 3 つの時期に区分される。そして第 3 ，第 4 ，第 5 ゴープラは，さら に一段と時代が下る造立であったと考えられた。これら 3 つのゴー プラ相互の造立時期, 時代の前後関係は, 技法に大きな差がなく詳 細は不明である。

本論考では, 調査可能な限られた遺構を対象とし, さらに局部的 な技法に注目することで, 技法の変遷を手がかりに遺構の建立年代 の推定と編年を試みている。したがってこの試みは限定的なもので ある。遺構の編年については, 今後もさまざまな視点から検討を加え, 総合的に判断していく必要がある。

\section{注記}

本調查研究は, 文部科学省科学研究費補助金の助成を受け, 平成 24 年度から実施した基盤研究 (A) ・海外「クメール帝国の空間構造 と地方拠点都市遺跡に関する研究」（研究代表者：溝口明則）と, 力 
ンボジア王国・プレア・ヴィヘア機構及び JASA との共同研究として 進めている遺跡群の保存修復に向けた学術的基礎研究の一環として 行ったものである。プレア・ヴィへアの木造小屋組に関する調査は 2013 年 8 月～ 2015 年 8 月に実施し, 田淵奈央, 中村みふみ, 出雲蓮人, 荻原周, 古賀友佳子, 黒岩千尋, 貞富陽介, 松本奈穗, 北井絵里沙 (以上, 早大大学院理工学研究科修士課程), 金子達哉, 高橋泉美, 成井至 (以 上, 早大理工学部建築学科), 中村嘉代子, 水谷惊志 (以上, 名城大 理工学部建築学科), 石塚充雅 (名城大学・早稲田大学チーム現地調 查員), 小岩正樹 (早稲田大学), 中川武 (早稲田大学, 博物館明治村), 溝口明則（名城大学，所属はいずれも調查当時）が参加した。なお, プレアヴィヘア寺院の調查においては, プレアヴィへア機構 H. E. Mr.Kim Sedara 総裁, H.E. Mr. UK Top Botra副総裁などの協力のも とに, 現地調査にて Pin Sopha 氏を中心に建築学および考古学スタッ フ数名が参加した。

\section{参考文献}

1) Parmentier, H. :L'art Khmer Classique, Monuments du Quadrant NordEst 2vols, Paris, EFE0, 1939.

2) Dumarçay, J. : Khmer roofs and tiles, Report of the Joint Study on Cultural Heritage Protection in Angkor, Nara National Research Institute of Cultural Properties, 1997.

J. デュマルセ：クメールの小屋組と瓦，アンコール文化遺産保護共同研 究報告書, 奈良国立文化財研究所, 1997 .

3 ) Sawada, Chika \& Ueno, Kunikazu: A reconstruction of wooden roof frames at Banteay Srei and Ta Prohm-Woodworking techniques in Khmer architecture, Transactions of AIJ: Journal of Architecture, Planning and Environmental Engineering vol. 623, pp 221 - 226, Jan. 2008.

澤田知香, 上野邦一：バンテアイ・スレイ, タ・プロム寺院の木造小屋組 に関する復原的考察 一クメール建築における木工技術について，日本建築 学会計画系論文集 第 623 号, pp. 221-226, 2008. 1.

\section{注}

注 1) Sahai S. :Preah Vihear An Introduction to the World Heritage Monument, Phnom Penh, Buddhist Institute Printing House, 2009.

注 2） ロルオス，プレア・コーの伽藍に木造屋根を失ったとみられる遺構が 残るが，壁体上部を喪失しており架構の痕跡を確認できない。ただ，内外 のゴープラや他の付属建物周辺に渦巻型ナーガの残欠が残る。これらの装 飾から推定される年代は，コー・ケーと同時代かやや新しい時期である。 また，同様に木造架構の疑いが残るサンボー・プレイクックのローバン・ ロミアス K 8 建物は，伽藍軸からずれ，周囲の建物がアンコール・ワット 期であることなどから後代の建物と推定されているが，論考の結論を先取 りすれば 11 世紀前半頃に下る建立が想定される。したがって今のところ， コー・ケー時代より遡る石造壁・木造小屋組遺構は見いだせない。

注 3 ）垂木を受ける浅い溝の断面はコの字型の輪郭を持つが，垂木の勾配に合 わせて室内側の側面に傾斜をつけている。なお，双首のような収まりにつ いては，バンテアイ・スレイにおいても「垂木の下端を敷桁に組み込む」 と指摘されている。参考文献 3 参照。

注 4 ）プラサート・トム東ゴープラのすぐ内側に位置する付属建物にて調査を 行った。また伽藍東端の「宮殿」においても，同様の仕口とともに垂木を 受ける線状の溝の痕跡が認められる。プラサート・トムにおいても遺構の 残存状態は良好ではなく, 木造架構の様相を残寸事例は限られる。

注 5 )「あり落とし」状の仕口は, 妻壁に近接する梁の仕口に限って使用される。 他はいずれも「相欠」様の仕口を持ち，意図して使い分けられたことは明 らかだが不明な点も残る。「あり落とし」は梁中央の垂下に起因する引張 力に対抗する工夫のようだが，10 世紀中頃以後の遺構には見られない。

注 6 ) 実測数值は実測場所によって相違がみられるが，以下に大略を示す。東
メボン付属建物の軒桁と梁の痕跡は, 軒桁断面が幅 $240 \mathrm{~mm}$ 前後, 高さは $130 \mathrm{~mm}$ 前後である。梁断面を幅と高さいずれも $240 \mathrm{~mm}$ 程とする。プレ・ル プ付属建物では軒桁痕跡の幅と高さが $200 \mathrm{~mm}$ と $250 \mathrm{~mm}$ 程。梁断面の痕跡は, 幅，高さともに $280 \mathrm{~mm}$ 程である。軒桁の断面がやや小さいが，垂木を受け る材であるから不自然ではない。一方，梁の断面は幅，高さをほぼ同寸と し，軒桁に比べて一回り太いことが明らかである。いずれも，軒桁，梁の 上面が石材上面と同一面を保っていたと推定している。

注 7 ）参考文献 $2 ）$ および 3 ）。J. デュマルセの復原案は, 壁体最上部に残る 痕跡を，天井を架けるための加工と見て，梁痕跡に従い天井下に梁を架け る。一方，澤田，上野両氏の復原案は，壁体最上に載る石材を改造時の補 足材と判断し，上部室内側の加工痕跡を新たに設けられた軒桁の跡とみて いる。改造を想定した的確な判断と考えられる。ただ, 改造に合わせて軒 桁位置を持ち上げたと判断しながらも，梁は当初位置を踏襲したとする。

注 8 ）一部,軒桁跡に充当したレンガが残る。当初材の軒桁が埋められた跡は, 改造後に建物外に露出する位置である。放置すれば雨水が溜まるなどの問 題が生ずるから，充填材を用いて埋められたことは確実である。

注 9 ) 木造時代の棟木, 母屋桁, 軒桁の木口は, 破風板を当て, 表から釷で留 めたと予想される。破風板は, 妻壁と屋根面の接合部を保護し, 弱点であ る母屋桁や棟木の木口を被覆する部材である。日本建築の破風と懸魚の働 きを兼㸚た，幅広の板材であったと予想される。ただ，桁の木口に釘留め とすると，木質繊維の断裂部分から浸水を起こす。このため釷留めの位置 をさらに被覆する部材, 「釘隠し」が必要になる。石造の破風の頂部と両 端のほか, 胴部に 2 つ程設けた花紋様の装飾は, 釷の頭を被覆する部材が 形象化されたものとみられる。木造時代にすでに装飾化が進んでいた可能 性があるが，石造化を契機に，一段と装飾的な変形が進んだであろう。

注 10)参考文献 2 ) にて, 木造の妻壁であった可能性が指摘されている。しかし, その詳細について積極的な言及はない。

注 11）母屋林の端を加工して「あり落とし」の仕口を設けた可能性も残るが, 痕跡の高さが小さいため,「契り」を用いたと判断する。

注 12）第 3 ゴープラの東付属建物に限らず，本来，梁と軒桁の敷面は同一面 を目指して施工されている。しかし，実際に軒桁や梁を石材の上面に据え る段階で，部材の座りが悪く収まり難いと，その場で石材の表面を調整し たのだと思われる。このため結果的に，わずかな整形の痕跡が残されるこ とになった。ただ，この様相が観察できる箇所は，どの遺構においても例 外であり，多くの仕口跡では，敷面に明確な調整の跡を残していない。

注 13）石造横架材上部内角を削りとった加工の状態は，敷面の凹凸が大きく 木造桁などを施設できる丁寧な整形ではない。したがって，垂木端を直接 掛けるための加工であったと判断する。

注 14）Fig. 7-03 に示したように，第 3 ゴープラ隅部の仕口痕跡は，敷面の西 端（写真上方）の輪郭よりも南端（写真左方）の輪郭の変形が激しいこと が判る。これは, 敷面の様相から南北に架けられた軒桁が下に位置し，こ のため相欠の仕口が開きやすく, 中空に踏み出した軒桁の垂下が大きくな り，その結果砂岩材の縁に損傷を与えたことを示している。

注 15）第 5 ゴープラの独立柱上では，微かだが林を下に梁を上に設置したと みられる痕跡が残っている。

注 16）改造後の痕跡がないため，梁の上面が軒桁の下端に接するプレア・ヴィ ヘア建物 $\mathrm{E}$ 同様の収まりであった可能性も残る。いずれの架構であって も，木造妻壁の耐用年限を考慮すれば，石造妻壁への改修の時期は，建立 後, 長くとも四半世紀から半世紀の範囲に収まると考えられる。

注 17）黑岩千尋, 中川武, 溝口明則 : プレア・ヴィヘア寺院の「口の字」型・ 「田の字」型建築形式について - 「付属建物」に見るクメール建築変遷史 の考察, 日本建築学学会計画系論文集 719 号, pp. 195-202,2016.1 上記論文では，プレア・ヴィへア建物 $\mathrm{E}$ と建物 $\mathrm{F}$ の建立年代を, 内田悦夫 氏 (岩石学) の調査結果に従い, ジャヤヴァルマン六世 (1080-1107) 頃, ほぼ同時代の建立として扱った。本論考では, 局部的な部材の扱いに限定 して編年を試みるが，技法から見たとき，両建物の建立は少し遡るようで あり，さらに建物 $\mathrm{E}$ の建立年代は建物 $\mathrm{F} よ り$ 遡るようにみえる。

注 18）編年の指標として, タ・ケオ付属建物の建立年代を 1000 年頃, 第 3 ゴー プラ東「一の字」平面建物（H）の建立を 1026 年頃とする。

注記 : 各図版に描いた木造の軒桁や梁，垂木は，いずれも収まりの様相を示す ためのものである。それぞれの部材の大きさや断面のプロポーション等 は，仕口跡などから想定された仮定に基づいたものである。 


\title{
Akinori MIZOGUCHI*, Takeshi NAKAGAWA **, Masaki KOIWA ***, Mitsumasa ISHIZUKA ${ }^{* * *}$ and Chihiro KUROIWA ****
}

\author{
* Guest Prof., Waseda University, Dr.Eng. \\ ** Director, Open Air Museum MEIJI-MURA, Emeritus Prof., Waseda University, Dr.Eng. \\ $*_{* *}$ Assoc. Prof., Facuity of Scicnce and Engineerring, Waseda University, Dr.Eng. \\ **** Technical Staff, Collaborative Project between National Authority for Preah Vihear and Meijo Univ. and Waseda Univ., M.Arch. \\ ***** Doctor's Student, Graduate School of Creative Science \& Engineering, Waseda University, M.Eng.
}

In the history of Khmer architecture, it is well known that there was a transition from wooden construction to stone construction during the early 10th century to the second half of the 11th century. Also well known in the course of transition there was a period when wooden roof structure with tile on the stone structure wall appeared. There was a famous study by J. Dumarcay on the construction of wooden roofs in these periods, and the critically revisited by Chika Sawada, Kunikazu Ueno, there are many unclear elements requiring further study. The connection of the wooden roof structure and stone structure wall was a very technical problem in the period of transition from wooden to stone structure.

This report studied and organized the process of transition of the pole plate and beam at the upper part of the stone wall with a central focus on Preah Vihear because the monument had a history of continuous extension and reconstruction from about end of the 9th century to 11th century. Additionally, a comparison with other temples constructed in a similar age showed similar trace elements with Preah Vihear. Concurrently, the result of this study includes a new proposal to the construction process of Preah Vihear adding to proposals by H. Parmentier, and S. Sahai.

Koh Ker monuments did not have a pole plate and put the beam directly on the stone structure wall, whereas the pole plate was generated after the East Mebon. The pole plate in this period was embedded in the upper face of the stone wall, and from around $1000 \mathrm{AD}$ was put on the upper face. There are many cases where stone parts had the decoration of roof tile on the outside. Although in the early period the beam was thicker than the pole plate and the beam was set under the pole plate, from around second quarter of the11th century the position of beam and pole plate reversed and beam set on the pole plate. The size of beam and pole plate became the same, and stone parts were used to cover the upper parts of the pole plate from rain water.

Based on this study, the phases of the construction process and period of each building in Preah Vihear can be proposed with the other temples being the benchmark of age had wooden roof structure on the stone structure wall. Each construction period is possible to define become in the later period if the same technique was applied the process shows the upper limit of the period.

1) Jayavarman IV (928-941): attached building in Prasat Thom, transept of the gopura in Prasat Krachap,

2) Rajendravarman II (944-968), third quarter of the 10th century: East Mebon, Pre Rup, attached building of Banteay Srei (before reconstruction)

3) Jayavarman V (968- around 1000), fourth quarter of 10th century?: attached building of Banteay Srei(after reconstruction), attached building of Ta Keo, preceding building shaped as "-" (center part of H') at the west of Gopura III and building E in Preah Vihear

4) Suryavarman I (1002-1050), end of 10th century - first quarter of 11 th century : Gopura I and II and west attached building shaped as “コ" (I') and east attached building shaped as “—” (H) of Gopura III, building F

5) Suryavarman I (1002-1050), second quarter of the 11th century: east attached building shaped as “コ” (I) of Gopura III

6) After Udayadityavarman II (1050-1066), second half of the 11th century - 12th century: Gopura III, IV, and V in Preah Vihear 